Abstracta Iranica Abstracta Iranica

Revue bibliographique pour le domaine irano-aryen

Volume 22 | 2001

Comptes rendus des publications de 1999

\title{
Les Alains. Cavaliers des steppes, seigneurs du Caucase. Paris, Errance, 1997, 176 p.
}

Étienne de La Vaissière

\section{(2) OpenEdition}

1 Journals

Édition électronique

URL : http://journals.openedition.org/abstractairanica/36134

DOI : 10.4000/abstractairanica.36134

ISSN : 1961-960X

\section{Éditeur :}

CNRS (UMR 7528 Mondes iraniens et indiens), Éditions de l'IFRI

\section{Édition imprimée}

Date de publication : 15 mai 2001

ISSN : 0240-8910

\section{Référence électronique}

Étienne de La Vaissière, «Les Alains. Cavaliers des steppes, seigneurs du Caucase. Paris, Errance, 1997, 176 p. », Abstracta Iranica [En ligne], Volume 22 | 2001, document 35, mis en ligne le 15 février 2010, consulté le 10 octobre 2020. URL : http://journals.openedition.org/abstractairanica/36134 ; DOI : https://doi.org/10.4000/abstractairanica.36134

Ce document a été généré automatiquement le 10 octobre 2020.

Tous droits réservés 


\title{
Les Alains. Cavaliers des steppes,
} seigneurs du Caucase. Paris, Errance, 1997, 176 p.

\author{
Étienne de La Vaissière
}

Dans une petite collection destinée aux amateurs avertis, les AA. donnent une utile synthèse sur les Alains et leur histoire, des origines au $16^{\mathrm{e}} \mathrm{s}$. Rédigé essentiellement par le meilleur spécialiste russe du sujet, V. Kouznetsov, cet ouvrage est particulièrement précieux pour la présentation de données archéologiques très dispersées dans les publications soviétiques. Bonnes illustrations, courte bibliographie.

INDEX

Thèmes : 1.3. Ouvrages généraux, histoire de la discipline

\section{AUTEURS}

ÉTIENNE DE LA VAISSIÈRE

ENS - Paris 